\title{
MORTADELLA SAUSAGE FORMULATIONS WITH MECHANICALLY SEPARATED LAYER HEN MEAT PREBLENDED WITH ANTIOXIDANTS
}

\author{
Marco Antonio Trindade ${ }^{1 *}$; Carmen Josefina Contreras Castillo²; Pedro Eduardo de Felício ${ }^{3}$ \\ ${ }^{1}$ USP/FZEA - Depto. de Engenharia de Alimentos, C.P. 23 - 13635-900 - Pirassununga, SP - Brasil. \\ ${ }^{2}$ USP/ESALQ - Depto. de Agroindústria, Alimentos e Nutrição, C.P. 9 - 13418-900 - Piracicaba, SP - Brasil. \\ ${ }^{3}$ UNICAMP/FEA - Depto. de Tecnologia de Alimentos, C.P. 6121 - 13083-862 - Campinas, SP - Brasil. \\ *Corresponding author <trindade@fzea.usp.br>
}

\begin{abstract}
At the end of the laying cycle, layer hens can be used for production of mechanically separated meat (MSML) for sausage manufacture. However, mechanically separated meats are susceptible to lipid and pigment oxidation during storage, problems that could be prevented by the use of antioxidants present in curing additives traditionally used in meat processing. The objective of this work was to evaluate the quality and stability of Mortadella produced with MSML added of sodium erythorbate (1000 ppm) and sodium nitrite $(150 \mathrm{ppm})$ through preblending or during chopper processing (control treatment), after long term frozen storage of raw meat ingredient. The products were stored for 40 days at $7^{\circ} \mathrm{C}$ and evaluated in regard to the oxidative stability of lipids (TBARS values), objective color, and microbiological and sensory attributes. Preblending MSML lessened rancidity of the final product in comparison to the control (0.2 and $2.2 \mathrm{mg}$ malonaldehyde per $\mathrm{kg}$, respectively), and elicited better color ( $\mathrm{a}^{*}=7.5$ and 10.5 , respectively). Total counts of psychrotrophic microorganisms were similar for both treatments $\left(2 \log \mathrm{CFU} \mathrm{g}^{-1}\right)$. Previous blending of nitrite $(150 \mathrm{ppm})$ and erythorbate $(1000 \mathrm{ppm})$ in mechanically separated meat soon after the extraction is recommended when the raw material will eventually go through prolonged frozen storage before its use in Mortadella sausage processing.

Key words: poultry meat, nitrite, erythorbate, oxidative stability, sensory evaluation
\end{abstract}

\section{MORTADELA ELABORADA COM CMS DE GALINHAS POEDEIRAS PRÉ-MISTURADA COM ANTIOXIDANTES}

\begin{abstract}
RESUMO: Uma das formas de utilização das galinhas poedeiras ao final do ciclo de postura é a obtenção de carne mecanicamente separada (MSML) para a elaboração de embutidos. Entretanto, carnes mecanicamente separadas apresentam alta susceptibilidade à oxidação lipídica e dos pigmentos. O uso de antioxidantes tradicionalmente utilizados na cura de carne para incorporação prévia à matéria prima poderia evitar estes problemas. Assim, o objetivo deste trabalho foi avaliar a qualidade e a estabilidade de mortadelas elaboradas com MSML com adição de eritorbato (1000 ppm) e nitrito (150 ppm), como pré-cura antes da estocagem congelada, ou durante o processamento no homogeneizador (cutter) de bacia rotativa (controle). Os embutidos foram avaliados durante 40 dias $\left(7^{\circ} \mathrm{C}\right)$ quanto à estabilidade oxidativa dos lipídios (índice de TBARS) e da cor objetiva, assim como a estabilidade microbiológica e sensorial. A pré-cura da MSML garantiu um produto final com menor rancidez quando comparado com o controle $(0,2$ e $2,2 \mathrm{mg}$ malonaldeído $/ \mathrm{kg}$, respectivamente) e melhor coloração (valores de a* entre 7,5 e 10,5, respectivamente) ao longo de todo o tempo de estocagem. As contagens totais de microrganismos psicrotróficos não diferiram entre os tratamentos (2 log UFC g $\left.{ }^{-1}\right)$. A mistura prévia de nitrito $(150 \mathrm{ppm})$ e eritorbato $(1000 \mathrm{ppm}) \mathrm{em}$ carne mecanicamente separada que possa vir a sofrer estocagem congelada prolongada antes de ser utilizada na elaboração de embutidos é recomendável.

Palavras-chave: carne de aves, nitrito, eritorbato, estabilidade, análise sensorial
\end{abstract}

\section{INTRODUCTION}

The number of layer hens housed in 2004 in Brazil was approximately 62.8 million (UBA, 2005). Volumes of biological wastes, labor and transportation costs associated with the disposal of layer hens, are some of the main economical and environmental prob- lems of the poultry industry (Lyons, 2001). Spent hens are normally slaughtered and made available for other uses, such as feed production, concentrated stock preparation, or domestic consumption as soups and stews (Ajuyha et al., 1992; Voller-Reasonover et al., 1997). Another end use for spent hens is the production of mechanically separated layer hen meat (MSML) 
for the sausage industry (Lee et al., 1997; Trindade et al., 2004; 2005).

Chemical and structural alterations during mechanical separation, the development of undesirable aromas (rancidity) and the loss of its characteristic red color, because of lipid and pigments oxidation, respectively, make mechanically separated meats having low stability during storage. Quality loss can also result from the redistribution of the higher initial microbial load from the more exposed areas and larger availability of nutrients, originated from the breakage of the cells, which favor the growth of microorganisms.

Because of its curing activity nitrite is an important ingredient in meat preblending, it functions also as anti-oxidant and in the production of the typical aroma of cured meats. Nitrite also has important antimicrobial effects, avoiding the production of toxins by Clostridium botulinum (Hasiak et al., 1984; Kolodziejska et al., 1990). A maximum of $150 \mathrm{ppm}$ of nitrite is allowed by the Brazilian food safety legislation in meat products (Brasil, 1998).

Sodium erythorbate is used in meat products to speed up the formation and stabilize the characteristic pink color of nitrite-cured meats. The utilization of antioxidants can minimize functional deteriorations in muscle proteins during storage (Xiong \& Decker, 1995). Erythorbate is an antioxidant, so this effect could also be expected. The Brazilian legislation does not limit the use of sodium erythorbate in sausages (Brasil, 1998).

This project was carried out to evaluate the quality and stability of Mortadella produced with MSML preblended or not with sodium erythorbate and sodium nitrite, and kept under frozen storage for 90 days before processing.

\section{MATERIAL AND METHODS}

\section{Raw Material}

Carcasses from 18 month-old White Leghorn hens were obtained from a local poultry slaughterhouse. Fifty carcasses were processed into MSML using a POSS extractor model PDE 1000. The average proximate composition for the MSML obtained was $15.15,16.89,63.94$, and $2.06 \%$ for protein, fat, moisture and ash, respectively. The MSML was separated in portions of $9.5 \mathrm{~kg}$, which were mixed for three minutes with either $0.5 \mathrm{~kg}$ of pure, distilled water (control treatment), or distilled water with dissolved additives (preblending treatment: $1.5 \mathrm{~g}$ of sodium nitrite and $10.0 \mathrm{~g}$ of sodium erythorbate, equivalent to 150 ppm and $1000 \mathrm{ppm}$, respectively). The raw material was then separately packed in polyethylene bags, and stored at $-18^{\circ} \mathrm{C}\left( \pm 1^{\circ} \mathrm{C}\right)$ for 90 days.

\section{Mortadella Formulation and Processing}

Table 1 shows the formulations (approx. $10 \mathrm{~kg}$ batches) used in both treatments. The MSML were chopped in a block cutter and then weighed; all ingredients and the ice were also separately weighed. The comminution was initially carried out in a cutter up to temperatures around $10^{\circ} \mathrm{C}$. The refinement of the masses was finished in a colloidal mill. The temperature of the masses was around $14^{\circ} \mathrm{C}$ after this process. Then, the emulsions were stuffed (around $500 \mathrm{~g}$ per unit) into $90 \mathrm{~mm}$-wide, impermeable plastic casings. They were cooked in a smokehouse until the internal temperature reached $72^{\circ} \mathrm{C}$ (approximately $120 \mathrm{~min}$.); the products were then cooled in a shower until the internal temperature dropped to $40^{\circ} \mathrm{C}$, and stored at $7^{\circ} \mathrm{C}$.

\section{Technological characterization}

Stability of the emulsions - Stability was determined using the method of Parks \& Carpenter (1987) with 10 replicates for each sample. Approximately 50g samples of emulsion were poured into plastic bags (PA/PEBD), which were sealed and cooked in a water bath at $70^{\circ} \mathrm{C}$ for $1 \mathrm{~h}$. The exudate was then weighed to determine the percentage of cooking loss.

pH - The $\mathrm{pH}$ was measured in a $\mathrm{pHmeter}$ with the electrode directly placed into the sample. Three measurements were made in products from each treatment.

Shear Force Value - Shear strength was measured using a TA - TX $2 \mathrm{i}$ texture analyzer equipped with a Warner-Bratzler device at a test speed of $20 \mathrm{~cm}$ $\min ^{-1}$. Ten samples were analyzed for each treatment. The samples were cut into $20 \mathrm{~mm}$ high and $13 \mathrm{~mm}$ diameter cylinders, compressed on their round surfaces

Table 1- Formulations used in Mortadella processing.

\begin{tabular}{|c|c|c|}
\hline & Preblending & Control \\
\hline \multicolumn{3}{|l|}{ Raw Material } \\
\hline MSML & $8.00 \mathrm{~kg}$ & $8.00 \mathrm{~kg}$ \\
\hline \multicolumn{3}{|l|}{ Ingredients } \\
\hline Salt & $200.0 \mathrm{~g}$ & $200.0 \mathrm{~g}$ \\
\hline Commercial condiment & $100.0 \mathrm{~g}$ & $100.0 \mathrm{~g}$ \\
\hline Soy protein & $100.0 \mathrm{~g}$ & $100.0 \mathrm{~g}$ \\
\hline Cassava starch & $500.0 \mathrm{~g}$ & $500.0 \mathrm{~g}$ \\
\hline Mashed garlic & $100.0 \mathrm{~g}$ & $100.0 \mathrm{~g}$ \\
\hline Sodium tripolyphosphate & $30.0 \mathrm{~g}$ & $30.0 \mathrm{~g}$ \\
\hline Sodium nitrite & $1.2 \mathrm{~g}^{*}$ & $1.2 \mathrm{~g}$ \\
\hline Sodium erythorbate & $8.0 \mathrm{~g}^{*}$ & $8.0 \mathrm{~g}$ \\
\hline Ice & $1.10 \mathrm{~kg}$ & $1.10 \mathrm{~kg}$ \\
\hline
\end{tabular}

*Sodium nitrite and sodium erythorbate were added to the MSML before the storage, as described above.

MSML: mechanically separated layer hen meat. 


\section{Evaluation of storage stability}

Stability tests were carried out every seven days, from day 5 through day 40 after processing. In each point, 2 units (500 g each) were evaluated.

\section{Thiobarbituric acid reactive substances (TBARS)}

Lipid oxidation was determined through TBARS, using the distillation method of Tarladgis et al. (1960). The modification to this procedure was the addition of butylated hydroxytoluene before blending, to prevent auto-oxidation (Pikul et al., 1983). The TBARS test, when performed with the distillation procedure, is considered to be more sensitive and also more suitable for high-fat samples $(>10 \%)$ where turbidity may occur in the extracted samples (Shahidi, 1998). The TBARS value was calculated from a standard curve, and expressed as mg Malonaldehyde $\mathrm{kg}^{-1}$ of the product. Three samples (10 g each) were analyzed for each treatment.

\section{Color measurements}

Objective color was measured using a portable Minolta spectrophotometer, model CM508d, with illuminant $\mathrm{C}$ and $\mathrm{a} 2^{\circ}$ angle. The readings for calibration and evaluation were performed using the CIE $\mathrm{L} * \mathrm{a} * \mathrm{~b} *$ scheme $(\mathrm{L} *=$ lightness, $\mathrm{a} *=$ redness, $\mathrm{b} *=$ yellowness). Measurements were made on six slices from each treatment.

\section{Microbiological analysis}

On the first and last days of the stability evaluation, the treatments were analyzed for Salmonella, faecal coliforms, sulfite-reducing clostridia, Staphylococcus aureus and enterobacteria. The total count of psychrotrophics was performed on all 6 sampling points. Microbial analysis was carried out according to the methodology described by Vanderzant \& Splittstoesser (1992). Detection limits for psychrotrophic aerobes, sulfite-reducing clostridia, Staphylococcus aureus and enterobacteria was $10 \mathrm{CFU}$, and $<3 \mathrm{MPN} \mathrm{g}^{-1}$ for fecal coliforms.

\section{Descriptive sensory evaluation}

Sensory analysis of the products during the shelf life was performed by odor and appearance evaluations, using intensity scales and sixteen experienced panelists. Attributes of pink color, rancid aroma, and fermented aroma were evaluated in non-structured scales of $10 \mathrm{~cm}$, representing "absent" at the beginning and "intense" at the end. Color evaluations were performed under regular white light, whereas odor evaluations were carried out under a green light, with the objective of disguising color differences among the different treatments.

\section{Statistical analysis}

Trials were set up in a completely randomized design with 2 treatments $(\mathrm{n}=2)$; measurements were made at days 5, 12, 19, 26, 33 and 40. Data were analyzed by ANOVA to compare results among the treatments and regression to study trends during the evaluation period. The means were compared using the Tukey's test. The $\mathrm{SAS}^{\circledR}$ (Copyright $^{\circ}$ 2004, SAS Institute Inc.) software with its proc mixed tool was used. A significance level $P=0.05$ was adopted.

\section{RESULTS AND DISCUSSION}

\section{Emulsions stability}

Preblending mechanically separated meat of white layer hens (MSML) did not affect stability of emulsions $(P>0.05)$ using this raw material as the only meat ingredient. The average values obtained in the emulsion stability tests were $2.59 \%(\mathrm{SEM}=0.13)$ of released juice in the CONT treatment (Mortadella made with MSML stored for 90 days with no previous addition of additives), and $2.70 \%($ SEM $=0.09)$ of released juice in the PRE treatment (Mortadella made with MSML stored for 90 days preblended with $150 \mathrm{ppm}$ of sodium nitrite and $1000 \mathrm{ppm}$ of sodium erythorbate).

pH

Addition of nitrite and erythorbate before storaging the MSML did not affect the final $\mathrm{pH}$ of the Mortadella. The elevated $\mathrm{pH}$ values of 6.68 for both treatments can be explained by the high content of mechanically separated meat (100\% MSML) used in the products. Higher $\mathrm{pH}$ values in emulsified meat products improve the emulsification capacity of the myofibrillar proteins and fluid retention (Field, 1988).

\section{Shear force value}

The values of the peak shear force registered were $0.34 \mathrm{~kg}(\mathrm{SEM}=0.03)$ for PRE, and $0.41 \mathrm{~kg}$ $(\mathrm{SEM}=0.02)$ for CONT; there were no differences $(P>0.05)$ between treatments. Data are in accordance with those reported by Smith (1987), who registered that texture of gels prepared from turkey mechanically separated meat (MSM), stored at $-20^{\circ} \mathrm{C}$ for 26 weeks, with or without antioxidants, was similar. On the other hand, minced chevon preblended either without additives (control) or with $2 \%$ ginger extract (GE) was used to prepare cooked chevon patties. The control patties had significantly lower shear force values than the GE patties (Reema-Raj et al., 2005). 


\section{Evaluation of storage stability}

\section{TBARS}

The average TBARS values for CONT were higher $(P<0.05)$ than those of PRE in every interval (Table 2). The levels of additives used (150 ppm of nitrite and $1000 \mathrm{ppm}$ of erythorbate) were enough to inhibit lipid oxidation during the storage of Mortadella. Sausages made with more than 15\% turkey MSM stored for 90 days presented high indices of TBARS, resulting in product with a poorer quality than that of sausages made with fresh MSM (Froning et al., 1971). Frankfurters made with $20 \%$ chicken MSM preblended with nitrite, ascorbate, and polyphosphate and stored for one, three, and six months, presented lower TBARS values than sausages made with control MSM (without preblending), when MSMs stored for up to six months were used (Pollonio, 1994). Chicken mince (CM) preblended with $5,7.5,10$, or $12.5 \mathrm{ppm}$ of alpha-tocopherol acetate (TA) had lower TBARS values and metmyoglobin percentages in comparison to the control sample (without preblending) in refrigerated storage, indicating better oxidative stability of the antioxidant-treated CM (Sahoo et al., 2004).

\section{Objective color}

CONT presented a lower average index for the red color $(P<0.05)$ than PRE throughout the entire storage period (Table 3). Preblending nitrite and erythorbate protected the pigments of the MSML against oxidation during frozen storage, keeping them available for the pink color development during the cooking process. A more reddish coloration was obtained in Mortadella made with preblended MSML in comparison to the non-preblended MSML product. These data are in accordance with results reported by Pollonio (1994), who found significantly lower a* values for sausages made with $20 \%$ chicken MSM stored for six months without additives, when compared to sausages made with MSM preblended with a combination of nitrite, ascorbate and polyphosphate, stored for the same period ( $\mathrm{a}^{*}=4.1$ and 6.9 , respectively).

\section{Microbiological Analyses}

No difference $(P>0.05)$ was detected between the average psychrotrophic microorganisms counts for any treatment or between the time intervals (Table 4). Counts were done weekly along the refrigerated storage. Several analyses were also carried out to elicit a

Table 2 - Mean values of the TBARS analyses in Mortadella made with preblended and non-preblended MSML during refrigerated storage period.

\begin{tabular}{lccccccc}
\hline & \multicolumn{5}{c}{ Storage time (days) malonaldehyde } \\
\cline { 3 - 7 } & & 5 & 12 & 19 & 26 & 33 & 40 \\
\hline \multirow{2}{*}{ CONT } & Average & $2.26 \mathrm{a}^{\mathrm{z}}$ & $2.25 \mathrm{a}$ & $2.33 \mathrm{a}$ & $2.27 \mathrm{a}$ & $2.36 \mathrm{a}$ & $2.27 \mathrm{a}$ \\
& SEM & 0.01 & 0.02 & 0.04 & 0.01 & 0.02 & 0.01 \\
\hline & Average & $0.21 \mathrm{~b}$ & $0.20 \mathrm{~b}$ & $0.22 \mathrm{~b}$ & $0.21 \mathrm{~b}$ & $0.23 \mathrm{~b}$ & $0.24 \mathrm{~b}$ \\
& SEM & 0.01 & 0.01 & 0.00 & 0.01 & 0.01 & 0.01 \\
\hline
\end{tabular}

${ }^{z}$ Means followed by different letters in the same column differ by Tukey's test $(\alpha=0.05)$. TBARS: thiobarbituric acid reactive substances. MSML: mechanically separated layer hen meat. CONT: mortadella made with MSML stored for 90 days at $-18^{\circ} \mathrm{C}$ without additives. PRE: mortadella made with MSML preblended with $150 \mathrm{ppm}$ of sodium nitrite and 1000 ppm of sodium erythorbate, previously stored for 90 days at $-18^{\circ} \mathrm{C}$. SEM: standard error of mean.

Table 3 - Means and standard errors of means of the a* values in preblended and non-preblended MSML Mortadella during refrigerated storage period.

\begin{tabular}{lcccccccc}
\hline & \multicolumn{5}{c}{ Storage time (days) } \\
\cline { 3 - 8 } & & 5 & 12 & 19 & 26 & 33 & 40 \\
\hline CONT & Average & $7.53 \mathrm{a}$ & $7.22 \mathrm{a}$ & $7.39 \mathrm{a}$ & $7.37 \mathrm{a}$ & $7.28 \mathrm{a}$ & $7.25 \mathrm{a}$ \\
\multirow{2}{*}{ PRE } & SEM & 0.60 & 0.01 & 0.02 & 0.01 & 0.04 & 0.21 \\
& Average & $10.6 \mathrm{~b}$ & $10.33 \mathrm{~b}$ & $10.36 \mathrm{~b}$ & $10.11 \mathrm{~b}$ & $10.46 \mathrm{~b}$ & $10.32 \mathrm{~b}$ \\
\hline
\end{tabular}

Means followed by different letters in the same column differ by Tukey's test $(\alpha=0.05)$. MSML: mechanically separated layer hen meat. CONT: mortadella made with MSML stored for 90 days at $-18^{\circ} \mathrm{C}$ without additives. PRE: mortadella made with MSML preblended with $150 \mathrm{ppm}$ of sodium nitrite and $1000 \mathrm{ppm}$ of sodium erythorbate, previously stored for 90 days at $-18^{\circ} \mathrm{C}$. SEM: standard error of mean. 
more detailed microbiological characterization of the products. The analyses were done at the beginning $\left(5^{\text {th }}\right.$ day) and at the end ( $40^{\text {th }}$ day) of the storage. Analyses were performed for the detection of microorganisms which are limited in Mortadella by the Brazilian legislation (ANVISA, 2001): Salmonella, faecal coliforms, sulphite reductant clostridia, and Staphylococcus aureus. Analyses were also performed for enterobacteria. None of these microorganisms were detected neither in CONT or PRE.

\section{Sensory Evaluation}

Panelists detected a more intense pink coloration $(P<0.05)$ shade in PRE than in CONT samples (Table 5). Considering that the redder the better the visual quality of the Mortadella, the product made with $100 \%$ preblended MSML was significantly better during the refrigerated storage. Results were similar to those obtained in the objective analysis of the red color (value $\left.a^{*}\right)$. PRE samples presented average $a^{*}$ values significantly higher than those obtained for CONT at all evaluated intervals during the refrigerated storage.
Attribute fermented aroma was used by the panelists to evaluate if the product presented a characteristic aroma of microbiological deterioration. The panel's averages did not differ $(P<0.05)$ between CONT and PRE, with values under one $(0=$ absent; $10=$ intense) along the refrigerated storage period (Table 5). Data obtained in the sensory evaluation of the fermented aroma match those registered for the microbiological (total count of psychrotrophic microorganisms), which were very low for both treatments along the entire storage period.

The rancid odor is directly related to the lipid oxidation in foods. In this sensory attribute, the results of the panel showed the presence of a higher $(P<0.05)$ rancid odor in CONT than in PRE Mortadella along the storage period (Table 5). Products elaborated with MSML stored without the addition of additives were thought to be more oxidized than the ones made with preblended MSML by the panelists. These results obtained in the sensory evaluation are also in accordance with the objective analyses, for the average of the TBARS values observed in the CONT samples were

Table 4 - Total count of psychrotrophic microorganisms in CONT and PRE Mortadella during refrigerated storage.

\begin{tabular}{lcccccc}
\hline & \multicolumn{5}{c}{ Storage period (days) } \\
\cline { 2 - 4 } & \multicolumn{1}{c}{5} & 12 & 19 & 26 & 33 & 40 \\
\hline CONT & $2.2 \mathrm{a}^{\mathrm{z}}$ & $1.9 \mathrm{a}$ & $2.1 \mathrm{a}$ & $2.0 \mathrm{a}$ & $2.0 \mathrm{a}$ & $2.0 \mathrm{a}$ \\
$\mathrm{PRE}$ & $2.2 \mathrm{a}$ & $1.7 \mathrm{a}$ & $1.9 \mathrm{a}$ & $1.9 \mathrm{a}$ & $1.8 \mathrm{a}$ & $1.9 \mathrm{a}$ \\
\hline
\end{tabular}

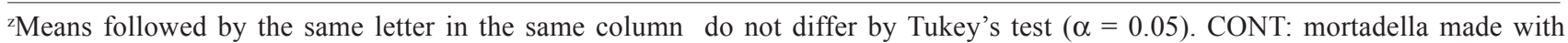
mechanically separated layer hen meat (MSML) stored for 90 days at $-18^{\circ} \mathrm{C}$ without additives. PRE: mortadella made with MSML preblended with $150 \mathrm{ppm}$ of sodium nitrite and $1000 \mathrm{ppm}$ of sodium erythorbate, previously stored for 90 days at $-18^{\circ} \mathrm{C}$.

Table 5 - Descriptive sensory analysis results of the CONT and PRE Mortadella during refrigerated storage $\left(7^{\circ} \mathrm{C}\right)$.

\begin{tabular}{|c|c|c|c|c|c|c|c|}
\hline \multirow{2}{*}{ Attribute } & & \multicolumn{6}{|c|}{ Storage period (days) } \\
\hline & & 5 & 12 & 19 & 26 & 33 & 40 \\
\hline \multirow[t]{4}{*}{ Pink color } & CONT & $1.66 \mathrm{a}^{\mathrm{z}}$ & $1.82 \mathrm{a}$ & $1.88 \mathrm{a}$ & $1.94 \mathrm{a}$ & $2.20 \mathrm{a}$ & $2.00 \mathrm{a}$ \\
\hline & SEM & 0.06 & 0.16 & 0.05 & 0.16 & 0.04 & 0.11 \\
\hline & PRE & $3.65 \mathrm{~b}$ & $4.42 \mathrm{~b}$ & $4.30 \mathrm{~b}$ & $4.72 \mathrm{~b}$ & $4.24 \mathrm{~b}$ & $4.44 b$ \\
\hline & SEM & 0.27 & 0.40 & 0.44 & 0.09 & 0.11 & 0.66 \\
\hline Fermented & CONT & $0.83 \mathrm{a}$ & $0.49 \mathrm{a}$ & $0.68 \mathrm{a}$ & 0.82 a & $0.56 \mathrm{a}$ & $1.10 \mathrm{a}$ \\
\hline \multirow[t]{3}{*}{ Aroma } & SEM & 0.15 & 0.01 & 0.07 & 0.06 & 0.10 & 0.06 \\
\hline & PRE & $0.35 \mathrm{a}$ & $0.38 \mathrm{a}$ & $0.50 \mathrm{a}$ & $0.53 \mathrm{a}$ & $0.38 \mathrm{a}$ & $0.72 \mathrm{a}$ \\
\hline & SEM & 0.14 & 0.03 & 0.05 & 0.17 & 0.02 & 0.04 \\
\hline Rancid & CONT & $4.40 \mathrm{a}$ & $4.42 \mathrm{a}$ & $4.72 \mathrm{a}$ & $4.06 \mathrm{a}$ & $4.17 \mathrm{a}$ & $4.58 \mathrm{a}$ \\
\hline \multirow[t]{3}{*}{ Aroma } & SEM & 0.09 & 0.20 & 0.14 & 0.12 & 0.48 & 0.21 \\
\hline & PRE & $1.76 \mathrm{~b}$ & $1.56 \mathrm{~b}$ & $1.84 \mathrm{~b}$ & $1.57 \mathrm{~b}$ & $1.60 \mathrm{~b}$ & $2.76 \mathrm{~b}$ \\
\hline & SEM & 0.43 & 0.52 & 0.05 & 0.61 & 0.30 & 0.29 \\
\hline
\end{tabular}

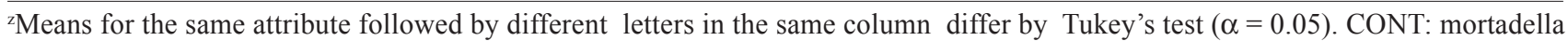
made with mechanically separated layer hen meat (MSML) stored for 90 days at $-18^{\circ} \mathrm{C}$ without additives. PRE: mortadella made with MSML preblended with $150 \mathrm{ppm}$ of sodium nitrite and $1000 \mathrm{ppm}$ of sodium erythorbate, previously stored for 90 days at $-18^{\circ} \mathrm{C}$. SEM: standard error of mean. 
higher $(P<0.05)$ than the ones observed for the PRE samples along the refrigerated storage, showing more lipid oxidation in CONT samples.

\section{ACKNOWLEDGEMENTS}

Authors thank FAPESP - Fundação de Amparo à Pesquisa do Estado de São Paulo for the financial support (Project $n^{\circ}$ 99/11489-1), and Dr. Nelson J. Beraquet for providing facilities and equipment for this research in the "Centro de Tecnologia de Carnes (CTC)", at the "Instituto de Tecnologia de Alimentos (ITAL)", Campinas, SP, Brasil.

\section{REFERENCES}

AJUYAH, A.O.; HARDIN, T.R.; CHEUNG, K.; SIM, J.S. Yield, lipid, cholesterol and fatty acid composition of spent hens fed full-fat oil seeds and fish meal diets. Journal of Food Science, v.57, p.338341, 1992.

AGÊNCIA NACIONAL DE VIGILÂNCIA SANITÁRIA - ANVISA. Leis, decretos, etc. Resolução-RDC no 12, 02 de jan.2001 da Agência Nacional de Vigilância Sanitária. Aprova o Regulamento Técnico sobre Padrões Microbiológicos para Alimentos. Diário Oficial, Brasília, 10 jan. 2001. Seção 1, p.45-47.

BRASIL. Ministério da Saúde. Leis, decretos, etc. Portaria no 1004, $11 /$ 12/1998 da Secretaria de Vigilância Sanitária do Ministério da Saúde. Regulamento Técnico “Atribuição de Função de Aditivos, Aditivos e seus Limites Máximos de Uso para a Categoria 8. Carnes e Produtos Cárneos". Diário Oficial, Brasília, 14 dez. 1998, nº 239-E. Seção 1, p. $28-32$

FIELD, R.A. Mechanically separated meat, poultry and fish. In: PEARSON, A.M.; DUTSON, T.R. (Ed.) Edible meat by-products. New York: Elsevier Applied Science, 1988. p.83-128.

FRONING, G.W.; ARNOLD, R.G.; MANDIGO, R.W.; NETH, C.E.; HARTUNG, T.E. Quality and storage stability of frankfurters containing $15 \%$ mechanically deboned turkey meat. Journal of Food Science, v.36, p.974-978, 1971.

HASIAK, R.J.; CHAVES, J.; SEBRANEK, J.; KRAFT, A.A. Effect of sodium nitrite and sodium eritorbate on the chemical, sensory and microbiological properties of water-adde turkey ham. Poultry Science, v.63, p.1364-1371, 1984.

KOLODZIEJSKA, I, SKONIECSNY, S.; RUBIN, L.J. Malondialdehyde-nitrite interactions in meat and model systems. Journal of Food Science, v.55, p.925-928, 946, 1990.

LEE, T.G.; WILLIAMS, S.K.; SOLAN, D.; LITTELL, R. Development and evaluation of a chicken breakfast sausage manufactured with mechanically deboned chicken meat. Poultry Science, v.76, p.415421, 1997.

LYONS, J.J. Spent hen utilization. e-DIGEST, v.1, 2001. Available in: $<$ http://www.wattnet.com/library/download/eD7sphened.pdf $>$. Accessed: Mar 18, 2005.

PARKS, L.L.; CARPENTER, J.A. Functionality of six nonmeat proteins in meat emulsion systems. Journal of Food Science, v.52, p.271274, 278, 1987.
PIKUL, J.; LESZCZYNSKI, D.E.; KUMMEROW, F.A. Elimination of sample autoxidation by butylated hydroxytoluene additions before thiobarbituric acid assay for malonaldehyde in fat from chicken meat. Journal of Agriculture and Food Chemistry, v.31, p.1338-1342, 1983.

POLLONIO, M.A.R. Estudo das propriedades funcionais das proteínas miofibrilares e oxidação lipídica de carne de frango mecanicamente desossada. Campinas: UNICAMP, 1994. 141p. (These - Doutorado).

REEMA-RAJ, R.; SAHOO, J.; HOODA, S.; KARWARASRA, R.K. Effect of ginger extract and cooking methods on oxidative stability and physico-chemical quality of vacuum packaged cooked chevon patties during storage. Journal of Food Science and Technology, v.42, p.275-279, 2005.

SAHOO, J.; KARWARASRA, R.K.; HOODA, S. Studies on alphatocopherol acetate as antioxidant in chicken mince on its quality during refrigerated storage. Journal of Food Science and Technology, v.41, p.240-243, 2004.

SAS INSTITUTE INC. SAS OnlineDoc ${ }^{\circledR}$ 9.1.3. Cary, NC: SAS Institute Inc, 2004.

SHAHIDI, F. Assessment of lipid oxidation and off-flavor development in meat, meat products and seafoods. In: SHAHIDI, F. (Ed.) Flavor of meat, meat products and seafoods. London: Blackie Academic \& Professional, 1998. cap.17, p.373-394.

SMITH, D.M. Functional and biochemical changes in deboned turkey due to frozen storage and lipid oxidation. Journal of Food Science, v.52, p.22-27, 1987.

TARLADGIS, B.G.; WATTS, B.M.; YOUNATHAN, M.T. A destilation method for the quantitative determination of malonaldehyde in rancid foods. The Journal of the American Oil Chemist's Society, v.37, p.44-48, 1960.

TRINDADE, M.A.; FELÍCIO, P.E. de; CONTRERAS, C.J.C. Mechanically separated meat of broiler breeder and white layer spent hens. Scientia Agricola, v.61, p.234-239, 2004.

TRINDADE, M.A.; CONTRERAS, C.J.C.; FELÍCIO, P.E. de . Mortadella sausage formulations with partial and total replacement of beef and pork backfat with mechanically separated meat from spent layer hens. Journal of Food Science, v.70, p.S236-S241, 2005.

UNIÃO BRASILEIRA DE AVICULTURA - UBA. Levantamento do alojamento de matrizes e comerciais. Acumulado planilhas UBA, Janeiro/dezembro/2004. Brasília, 2005. Available in: <http:// www.uba.org.br/banco/2004/banco-2004.html >. Accessed: Feb. 21, 2005.

VANDERZANT, C.; SPLITTSTOESSER, D.F. Compendium of methods for the microbiological examination of foods. 3 .ed. Washington, D.C: APHA, 1992.

VOLLER-REASONOVER, L.; HAN, I.Y.; ACTON, J.C.; TITUS, T.C.; BRIDGES, W.C.; DAWSON, P.L. High Temperature processing effects on the properties of fowl meat gels. Poultry Science, v.76, p.774-779, 1997.

XIONG, Y.L.; DECKER, E.A. Alterations of muscle protein functionality by oxidative and antioxidative processes. Journal of Muscle Foods, v.6, p.139-160, 1995.

Received June 20, 2005

Accepted April 03, 2006 